\title{
Mapping 18S ribosomal genes in fish of the genus Brycon (Characidae) by fluorescence in situ hybridization (FISH)
}

\author{
Adriane Pinto Wasko and Pedro Manoel Galetti Jr.
}

\begin{abstract}
The present study provides data on the nucleolar organizer regions (NORs) of seven Brycon species based on mapping of the 18S rRNA genes by fluorescence in situ hybridization (FISH). Fluorescent signals were observed on the telomere of the long arm of two large submetacentric chromosomes, thus confirming the number and location of NORs previously revealed by other classical cytogenetic techniques. Although there were no inter- or intra-individual variations in the number and location of the 18S loci, NOR size polymorphism was observed between homologous chromosomes. The clustering and conservation of NORs in a single chromosome pair indicates a high level of NOR stability among species of the genus Brycon.
\end{abstract}

\section{INTRODUCTION}

The nucleolar genes for ribosomal RNA (rDNA) are organized as multiple copies of a repeated unit that consists of a transcribed zone with coding regions for the $18 \mathrm{~S}, 5.8 \mathrm{~S}$ and 28S RNA genes separated by internal and external transcribed spacers and surrounded by non-transcribed spacer sequences (for review, see Long and David, 1980).

Nucleolar organizer regions (NORs) have been studied in many fishes using silver nitrate (Ag-NOR), mithramycin (MM) or chromomycin $\mathrm{A}_{3}\left(\mathrm{CMA}_{3}\right)$ staining (Amemiya and Gold, 1986; Phillips et al., 1989; Galetti Jr. and Rasch, 1993; Sola et al., 1997). Silver staining is more suitable for studying NOR expression because it detects only transcriptionally active NORs (Goodpasture and Bloom, 1975; Hofgatner et al., 1979; Howell and Black, 1980). GC-specific fluorochromes (MM, CMA $\left.{ }_{3}\right)$ stain both active and inactive NORs in fish and amphibians (Mayr et al., 1986; Schmid and Guttenbach, 1988; Phillips and Hartley, 1988), probably as a consequence of the higher GC content of rDNA (Schmid and Guttenbach, 1988), but they can also detect different chromosome regions.

The location of NORs has been confirmed by isotopic and non-isotopic in situ hybridization of rRNA or rDNA probes in fixed chromosomes of several vertebrates, including amphibians, humans, chimpanzees (for review, see Long and David, 1980) and, more recently, fishes (Pendás et al., 1993a,b; Castro et al., 1996; Viñas et al., 1996; Abuín et al., 1996; Gornung et al., 1997; Martins and Galetti Jr., 1998). Both Ag and CMA staining have been used in several species of the Brycon genus (Margarido and Galetti Jr., 1996; Almeida-Toledo et al., 1996).

In the present study, fluorescence in situ hybridization (FISH) was used to determine the chromosome loca- tion of the 18S rDNA genes of seven species of the genus Brycon, and to screen for additional minor rDNA units not detected by conventional techniques.

\section{MATERIAL AND METHODS}

Samples and mitotic chromosomal preparations

Seven species of the genus Brycon from different regions in Brazil were studied (Table I). Mitotic chromosomes were obtained from a suspension of anterior kidney cells using direct preparations (Bertollo et al., 1978) and short-term solid tissue culture (Fenocchio et al., 1991).

\section{Fluorescence in situ hybridization}

The rDNA probe was produced by a polymerase chain reaction (PCR) using genomic DNA from Brycon lundii (extracted from liver) and primers for the $18 \mathrm{~S}$ genes (Hizume, 1994). The probe was isolated from agarose gels

Table I - Species of the genus Brycon and collection sites.

\begin{tabular}{|llrr|}
\hline & & \multicolumn{2}{c|}{$\mathrm{N}$} \\
\cline { 2 - 4 } Species & Collection sites & $\mathrm{F}$ & $\mathrm{M}$ \\
\hline B. lundii & São Francisco River & & \\
& $\quad$ (Três Marias, MG) & 6 & 8 \\
B. orbignyanus & Paraná River (Porto Rico, PR) & 1 & 4 \\
B. microlepis & Cuiabá River (Cuiabá, MT) & 10 & 5 \\
B. brevicauda & Araguaia River (Aragarças, GO) & 6 & 5 \\
Brycon sp. & Araguaia River (Aragarças, GO) & 1 & - \\
B. cephalus & Amazonas River (Manaus, AM) & 3 & 2 \\
B. insignis & Paraíba do Sul River & & \\
& (Pindamonhangaba, SP) & 2 & 3 \\
\hline
\end{tabular}

$\mathrm{N}=$ Analyzed individuals, $\mathrm{F}=$ females, $\mathrm{M}=$ males 
using a commercial kit (Sephaglas ${ }^{\mathrm{TM}}$ BandPrep Kit, Pharmacia Biotech) and labeled with biotin-14-dATP by nick translation according to the kit manufacturer's instructions (Bionick ${ }^{\mathrm{TM}}$ Labeling System, Gibco). Prior to hybridization, the metaphase chromosome slides were pretreated with RNase $(40 \mu \mathrm{g} / \mathrm{ml}$ in 2x SSC) and incubated for one hour in a moist chamber at $37^{\circ} \mathrm{C}$ followed by dehydration in an ethanol series. The slides were subsequently denatured in $70 \%$ formamide $/ 2 \times \mathrm{SSC}$ at $70^{\circ} \mathrm{C}$ for $5 \mathrm{~min}$ and then dehydrated in an ethanol series at $-20^{\circ} \mathrm{C}$. Forty microliters of the hybridization mixture, containing $1 \mu \mathrm{g}$ of denatured probe, $50 \%$ formamide, $50 \%$ dex- tran sulfate and 2x SSC, was applied to each slide under a glass coverslip. After overnight incubation at $37^{\circ} \mathrm{C}$ in a moist chamber, the slides were washed in $50 \%$ formamide/ $2 \mathrm{x} \mathrm{SSC}$ at $37^{\circ} \mathrm{C}$ (15 min), in 2x SSC (twice, 15 min each) and in 4x SSC (10 min). Avidin-fluorescein isothiocyanate (FITC) conjugate (Sigma) was added to the slides which were then incubated at $37^{\circ} \mathrm{C}$ in a moist chamber for one hour. The slides were subsequently immersed three times (5 min each) in blocking buffer $\left(\mathrm{NaHCO}_{3}\right.$, sodium citrate, Triton 20 , nonfat dry milk) at $42^{\circ} \mathrm{C}$. Biotinylated anti-avidin antibody was applied to the slides followed by incubating at $37^{\circ} \mathrm{C}$ in a moist chamber for $30 \mathrm{~min}$ and washing
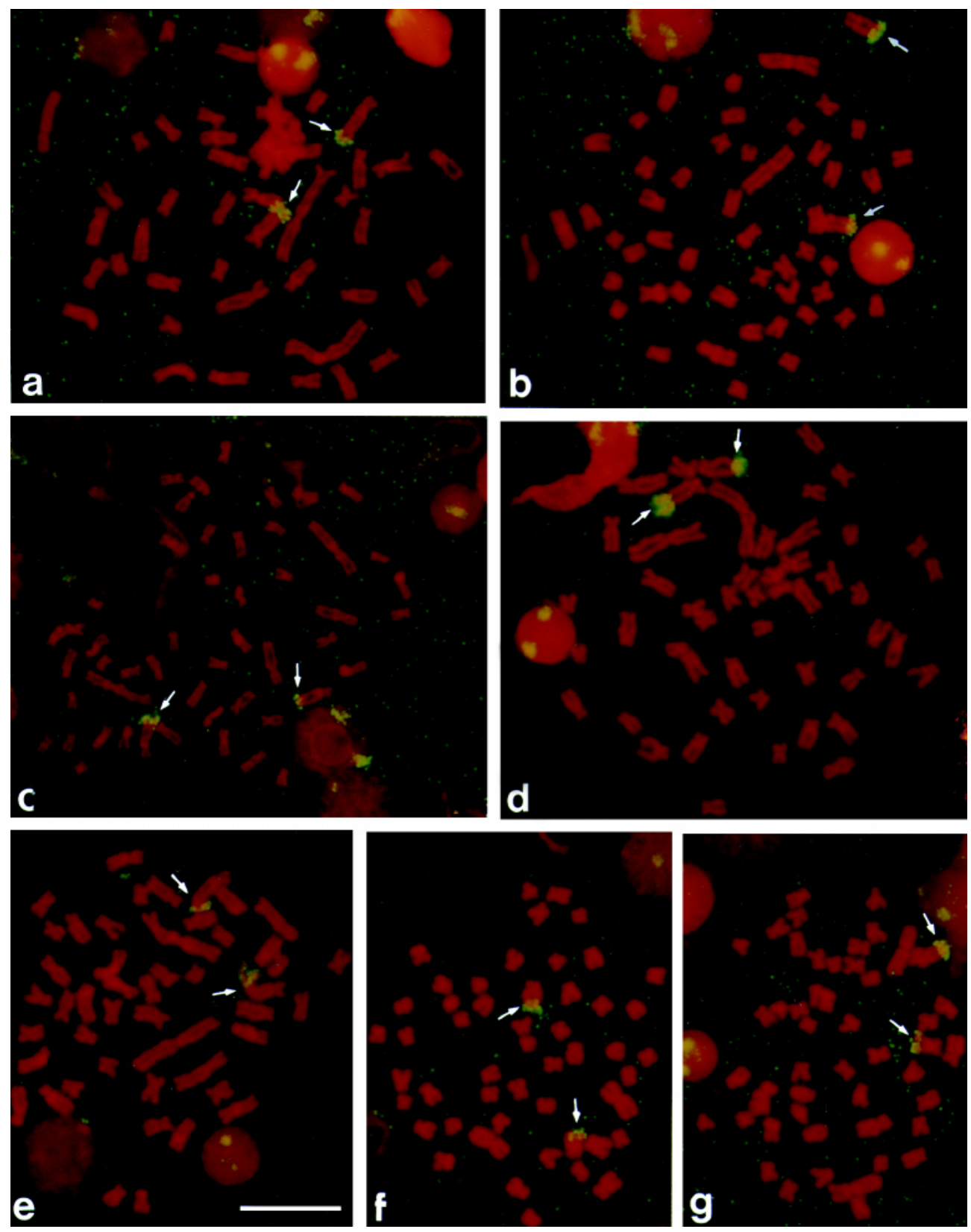

Figure 1 - 18S rDNA-FISH in Brycon. (a) B. brevicauda, (b) B. cephalus, (c) B. microlepis, (d) B. orbignyanus, (e) B. lundii, (f) Brycon sp., (g) B. insignis. Arrows indicate rDNA sites. Bar $=3 \mu \mathrm{m}$. 
in the same buffer. The signal was enhanced by biotinylated anti-avidin and avidin-fluorescein. The slides were washed twice ( 3 min each) in 2\% Triton 20/4x SSC after which they were mounted with fluorescence antifade solution (Vectashield antifade-Vector). The DNA counterstain propidium iodide $(50 \mu \mathrm{g} / \mathrm{ml})$ was included in the antifade solution. Metaphases were examined with an Olympus BX50 epifluorescence microscope. Photographs were taken using 400 ASA Kodak Gold Ultra film for color slides.

\section{RESULTS AND DISCUSSION}

The chromosomal organization of the seven species analyzed has been described in previous reports (Vascon et al., 1984; Bigoni et al., 1993; Margarido and Galetti Jr., 1996; Almeida-Toledo et al., 1996). A karyotype of 2n $=50$, consisting of metacentric, submetacentric and subtelocentric chromosomes, is characteristic for the Bryconinae group

Fluorescence in situ hybridization with a specific $18 \mathrm{~S}$ rDNA probe resulted in a large, bright fluorescent signal spread over the terminal region of the long arm of a large submetacentric pair, and corresponded to the NORbearing chromosomes in all of the species (Figure 1). No additional fluorescent signals were detected and one or two nucleoli were observed in interphase cells.

The detection of NORs in a single chromosome pair agreed with previous data obtained by silver nitrate and GC-specific fluorochrome staining (Margarido and Galetti Jr., 1996; Almeida-Toledo et al., 1996) and confirmed the existence of a single locus for this gene family in the seven species of the genus Brycon. The maximum number of nucleoli observed in interphase cells also highlighted the absence of other 18S rDNA sites.

Although FISH revealed no inter- or intraindividual variations in the number and location of the $18 \mathrm{~S}$ loci, heteromorphism in the size of the fluorescent signal was often detected between homologous chromosomes (see especially Figure 1d,e).

Variation in NOR size between homologous chromosomes is common in many vertebrates, including fishes (Foresti et al., 1981), in which NORs have been detected by Giemsa, C-banding, silver nitrate and mithramycin staining (Mestriner et al., 1995) and by rDNA-FISH (e.g. Wiberg, 1983; Sola et al., 1984; Viñas et al., 1996). Regional chromosomal duplications, produced either by DNA polymerase slippage or unequal crossing over (Warburton and Henderson, 1979; Jhanwar et al., 1981), could lead to the observed structural polymorphism. Moreover, genetic redundancy of rDNA regions and the tendency for association in nucleolar organization could facilitate non-reciprocal translocations between NORs (Goodpasture and Bloom, 1975; Ruiz, 1982; Schmid et al., 1987).

C-banding patterns (Margarido and Galetti Jr., 1996) for the species of the genus Brycon studied here indicate that the terminal region of the long arms of the NOR-bearing chromosomes consists mainly of constitutive heterochromatin, a common feature among other fish species (Moreira-Filho et al., 1984; Galetti Jr. et al., 1991; Pendás et al., 1993a,b; Martínez et al., 1996). The rDNA appears to be interspersed or adjacent to heterochromatin segments in these fishes (Pendás et al., 1993b; Galetti Jr. et al., 1995), and size polymorphism may be facilitated by this heterochromatin in the species of the genus Brycon.

The presence of NORs clustered and conserved in a single chromosome pair is a common character of all studied Brycon species and may be a primitive feature in the subfamily Bryconinae. This finding indicates a remarkable stability of the NOR phenotype pattern among these fishes.

\section{ACKNOWLEDGMENTS}

The authors thank Yoshimi Sato (Companhia de Desenvolvimento do Vale do São Francisco) for collecting the specimens. Research supported by Fundação de Amparo à Pesquisa do Estado de São Paulo (FAPESP) and Conselho Nacional de Desenvolvimento Científico e Tecnológico (CNPq). Publication supported by FAPESP.

\section{RESUMO}

O presente estudo fornece dados sobre as regiões organizadoras de nucléolos (NORs) de sete espécies do gênero Brycon, obtidos através da localização dos genes RNAr 18S por hibridação in situ fluorescente (FISH). Sinais fluorescentes foram observados no telômero do braço longo de dois cromossomos submetacêntricos grandes e confirmaram o número e a localização das regiões organizadoras de nucléolos anteriormente detectadas através de outras técnicas citogenéticas clássicas. Embora não tenham sido detectadas variações inter ou intraindividuais no número e localização dos loci $18 \mathrm{~S}$, um polimorfismo de tamanho na região organizadora de nucléolo foi observado entre os dois homólogos. O alto nível de estabilidade das NORs observado no gênero Brycon é caracterizado pela presença destes sítios agrupados e conservados em um único par de cromossomos nestes peixes.

\section{REFERENCES}

Abuín, M., Clably, C. and Martínez, P. (1996). A NOR-associated repetitive element present in the genome of two Salmo species (Salmo salar and Salmo trutta). Genome 39: 671-679.

Almeida-Toledo, L.F., Bigoni, A.P., Bernardino, G., Foresti, F. and ToledoFilho, A.S. (1996). Karyotype and NOR conservatism with heterochromatin reorganization in neotropical bryconids. Caryologia 49: 35-43.

Amemiya, C.T. and Gold, J.R. (1986). Chromomycin A stains nucleolus organizer regions of fish chromosomes. Copeia 1986: 226-231.

Bertollo, L.A.C., Takahashi, C.S. and Moreira-Filho, O. (1978). Cytotaxonomic consideration on Hoplias lacerdae (Pisces, Erythrinidae). Rev. Bras. Genet. I: 103-120.

Bigoni, A.P., Almeida-Toledo, L.F., Toledo-Filho, S.A. and Foresti, F. (1993) Estudos citogenéticos em três espécies de Bryconinae (Pisces, Characidae). Rev. Bras. Genet. 16 (Suppl.): A. 143.

Castro, J., Viñas, A., Sánchez, L. and Martínez, P. (1996). Characterization of an atypical NOR site polymorphism in brown trout (Salmo truta) with $\mathrm{Ag}$ - and $\mathrm{CMA}_{3}$-staining, and fluorescent in situ hybridiza- 
tion. Cytogenet. Cell Genet. 75: 234-239.

Fenocchio, A.S., Venere, P.C., Cesar, A.C.G., Dias, A.L. and Bertollo, L.A.C. (1991). Short term culture from solid tissues of fishes. Caryologia 44 : 161-166.

Foresti, F., Toledo, L.F., Almeida, S.A. and Toledo, F. (1981). Polymorphic nature of nucleolus organizer regions in fishes. Cytogenet. Cell Genet. 31: $137-144$

Galetti Jr., P.M. and Rasch, E.M. (1993). Chromosome studies in Poecilia latipunctata with NORs polymorphism as shown by silver nitrate and chromomycin $\mathrm{A}_{3}$ (Teleostei: Poeciliidae). Ichthyol. Explor. Freshwaters 4: 269-277.

Galetti Jr., P.M., Cesar, A.C.G. and Venere, P.C. (1991). Heterochromatin and NORs variability in Leporinus fish (Anostomidae, Characiformes). Caryologia 44: 287-292.

Galetti Jr., P.M., Mestriner, C.A., Monaco, P.J. and Rasch, E.M. (1995). Post-zygotic modifications and intra- and inter-individual nucleolar organizing region variations in fish: report of a case involving Leporinus fridereci. Chromosome Res. 3: 285-290.

Goodpasture, C. and Bloom, S.E. (1975). Visualization of nucleolar organizer regions in mammalian chromosomes using silver staining. Chromosoma 53: 37-50.

Gornung, E., Gabrielli, I., Cataudella, S. and Sola, L. (1997). CMA -banding pattern and fluorescence in situ hybridization with $18 \mathrm{~S}$ rRNA genes in zebrafish chromosomes. Chromosome Res. 5: 40-46.

Hizume, M. (1994). Allodiploid nature of Allium wakegi Araki revealed by genomic in situ hybridization and localization of $5 \mathrm{~S}$ and $18 \mathrm{~S}$ rDNAs Jpn. J. Genet. 69: 407-415.

Hofgatner, F.J., Krone, W. and Jain, K. (1979). Correlated inhibition of ribosomal RNA synthesis and silver staining actinomycin D. Hum. Genet. 47: 329-333.

Howell, W.M. and Black, D.A. (1980). Controlled silver-staining of nucleolus organizer regions with a protective colloidal developer: a 1-step method. Experientia 36: 1014-1015.

Jhanwar, S.C., Prensky, W. and Chaganti, R.S.K. (1981). Localization and metabolic activity of ribosomal genes in Chinese hamster meiotic and mitotic chromosomes. Cytogenet. Cell Genet. 30: 39-46.

Long, E.O. and David, I.D. (1980). Repeated genes in eukaryotes. Annu. Rev. Biochem. 49: 727-764.

Margarido, V.P. and Galetti Jr., P.M. (1996). Chromosome studies in fish of the genus Brycon (Characiformes, Characidae, Bryconinae). Cytobios 85: 219-228

Martínez, J.L., Morán, P., Garcia-Vázquez, E. and Pendás, A.M. (1996). Chromosomal localization of the major and 5S rRNA genes in the European eel (Anguilla anguilla). Cytogenet. Cell Genet. 73: 149-152.

Martins, C. and Galetti Jr., P.M. (1998). Karyotype similarity between two sympatric Schizodon fish species (Anostomidae, Characiformes) from the Paraguay River basin. Genet. Mol. Biol. 21: 355-360.

Mayr, B., Kalat, M. and Rab, P. (1986). Localization of NORs and counterstain-enhanced fluorescence studies in Salmo gairdneri and Salmo trutta. Theor. Appl. Genet. 71: 703-707.

Mestriner, C.A., Bertollo, L.A.C. and Galetti Jr., P.M. (1995). Chromosome banding and synaptonemal complexes in Leporinus lacustris (Pisces, Anostomidae): analysis of a sex system. Chromosome Res. 3: 440-443.

Moreira-Filho, O., Bertollo, L.A.C. and Galetti Jr., P.M. (1984). Structure and variability of nucleolar organizer regions in Parodontidae fish. Can. J. Genet. Cytol. 26: 564-568.

Pendás, A.M., Morán, P. and Garcia-Vázquez, E. (1993a). Ribosomal RNA genes are interspersed throughout a heterochromatic chromosome arm in Atlantic salmon. Cytogenet. Cell Genet. 63: 128-130.

Pendás, A.M., Morán, P. and Garcia-Vázquez, E. (1993b). Multichromosomal location of ribosomal RNA genes and heterochromatin association in brown trout. Chromosome Res. 1: 63-67.

Phillips, R.B. and Hartley, S.E. (1988). Fluorescent banding patterns of the chromosomes of the genus Salmo. Genome 30: 193-197.

Phillips, R.B., Pleyte, K.A., Van Ert, L.M. and Hartley, S.E. (1989). Evolution of nucleolar organizer regions and ribosomal RNA genes in Salvelinus. Physiol. Ecol. Jpn. 1: 429-447.

Ruiz, I.R.G. (1982). Organizadores nucleolares e evolução cariotípica em anfíbios poliplóides. Ciênc. Cult. 34: 470-473.

Schmid, M. and Guttenbach, M. (1988). Evolutionary diversity of reverse (R) fluorescent chromosome bands in vertebrates. Chromosoma 97: 101-114.

Schmid, M., Vitelli, L. and Batistoni, R. (1987). Chromosome banding in Amphibia. IV. Constitutive heterochromatin, nucleolus organizers, $18 \mathrm{~S}+28 \mathrm{~S}$ and $5 \mathrm{~S}$ ribosomal RNA genes in Ascaphidae, Pipidae, Discoglossidae and Pelobatidae. Chromosoma 95: 271-284.

Sola, L., Camerini, B. and Cataudella, S. (1984). Cytogenetics of Atlantic eels: C- and G-banding, nucleolus organizer regions, and DNA content. Cytogenet. Cell Genet. 38: 206-210.

Sola, L., Galetti Jr., P.M., Monaco, P.J. and Rasch, E.M. (1997). Cytogenetics of bisexual/unisexual species of Poecilia. VI. Additional nucleolus organizer region of Poecilia formosa (Amazon molly) from Texas, with a survey of chromosomal clones detected in Amazon molly. Heredity 78: 612-619.

Vascon, S.A., Pileggi, M. and Moreira-Filho, O. (1984). Estudos citogenéticos em Brycon lundii (Pisces, Characidae). Ciênc. Cult. 36 (Suppl.): 813.

Viñas, A., Gómez, C., Martínez, P. and Sánchez, L. (1996). Localization of rDNA genes in European eel (Anguilla anguilla) by FISH. Genome 39: $1220-1223$.

Warburton, D. and Henderson, A.S. (1979). Sequential silver staining and hybridization in situ of nucleolus organizer regions in human cells. Cytogenet. Cell Genet. 24: 168-175.

Wiberg, U.H. (1983). Sex determination in the European eel (Anguilla anguilla L.). Cytogenet. Cell Genet. 36: 589-598.

(Received December 7, 1998) 